\title{
ARTIKKELI
}

PEKKA METSO, LAURA KALLATSA, SINI MIKKOLA, TALVIKKI AHONEN

\section{\ Kokemukset hengellisestä yhteydestä ja hengellisyyden muutoksesta koronapandemian aikana Suomen ortodoksisessa ja evankelis-luterilaisessa kirkossa}

\section{Tiivistelmä}

Artikkeli tarkastelee Suomen ortodoksisen ja Suomen evankelis-luterilaisen kirkon toimintaan osallistuneiden $(\mathrm{N}=555)$ kokemuksia hengellisestä yhteydestä ja muutoksista omassa hengellisyydessä koronaepidemian ensimmäisen aallon aikana. Hengellisen yhteyden käsite pitää sisällään seurakunta-, ehtoollis- ja rukousyhteyden. Tutkimusaineistomme koostuu kahdesta kyselylomakeaineistosta: ortodoksisen kirkon striimattuihin jumalanpalveluksiin osallistuneiden tuottamasta aineistosta $(\mathrm{N}=330)$ ja evankelis-luterilaisen kirkon toimintaan pandemian aikaan osallistuneiden tuottamasta aineistosta $(\mathrm{N}=225)$. Uskonnollisten yhteisöjen merkitys yhteiskunnallisissa kriiseissä on vahvistunut, ja ihmiset hakeutuvat kirkon toimintojen piiriin. Kyselyyn vastanneiden kokemus hengellisestä yhteydestä etäyhteyksien aikana oli varsin jakaantunutta: osa koki hengellisen yhteyden vahvistuvan esimerkiksi uudenlaisten yhteyksien syntymisen myötä ja oman autonomian lisääntyessä suhteessa kirkon tilaisuuksiin osallistumiseen. Osa koki lähinnä verkkoyhteyksien kautta tapahtuvan toiminnan vieraannuttavan heitä ja seurakuntayhteyden jopa katkeavan. Hengellisyyden muuttuminen näkyy etenkin koronapandemian heijastumisena rukousaiheisiin sekä rukouselämän ja uskon syventymiseen. Ortodoksiaineistossa korostui tämän lisäksi pyhien läsnäolon voimakkaampi kokeminen.

Avainsanat: COVID-19, etäyhteys, hengellinen yhteys, hengellisyys, Suomen evankelis-luterilainen kirkko, Suomen ortodoksinen kirkko 


\section{Koronakriisi, kirkot ja hengellinen hyvinvointi}

Globaali koronapandemia on vaikuttanut laaja-alaisesti suomalaiseen yhteiskuntaan. Koronakriisi on koetellut kansantaloutta, yhteiskunnan huoltovarmuutta, palvelujen turvaamista ja terveydenhuollon kantokykyä sekä kuormittanut kansalaisten henkistä kestävyyttä ja vaikuttanut heidän elämäänsä monin tavoin, mahdollisesti pitkäkestoisesti. Kriisien on yleisesti ottaen todettu lisäävän terveyserojen kasvua väestöryhmien välillä ja kasvattavan niin elinajanodotteeseen, sukupuoleen kuin sosioekonomiseen asemaan liittyvää eriarvoisuutta. Koronakriisin vaikutuksia ja suomalaisten jaksamista alettiinkin selvittää pian poikkeusolojen käynnistyttyä. Valtioneuvoston toukokuussa 2020 julkaiseman raportin mukaan koronatilanteen sosiaaliset vaikutukset näkyivät varsin pian muun muassa perheiden hyvinvoinnissa ja jaksamisessa. (Valtioneuvosto, 2020:30, 44-45).

Koronakriisiin on Suomessa reagoitu yhteiskunnallisena häiriötilana, jossa toimitaan yhteiskunnan turvallisuusstrategiassa kuvatun kokonaisturvallisuuden yhteistoimintamallin mukaisesti. Yhteistoimintamalli kattaa keskeiset toimijat yksittäisestä kansalaisesta eri viranomaisiin. Yhteiskunnan elintärkeistä toimista huolehtivat myös uskonnolliset yhteisöt. Kirkkojen rooli yhteiskunnan toiminnan turvaamisessa tunnistetaan etenkin henkisen kriisinkestävyyden alueella, jolla tarkoitetaan "yksilöiden, yhteisöjen ja yhteiskunnan sekä kansakunnan kykyä kestää kriisitilanteiden aiheuttamat henkiset paineet ja selviytyä niiden vaikutuksilta." (Valtioneuvosto, 2017:5-6, 22-23.) Keväällä 2020 kerätyn aineiston mukaan suomalaisten suurimpia koronakriisistä johtuvia huolenaiheita olivat terveyteen ja talouteen liittyvät asiat (Salomäki, 2020c:3-7). Poikkeusolojen taloudelliset, sosiaaliset, psyykkiset ja hengelliset vaikutukset näkyivätkin nopeasti kirkkojen toimialoilla (Salomäki, 2020b:2-4).

Tutkimusten mukaan usko voi lisätä hyvinvointia ja toiveikkuutta vaikeissa elämäntilanteissa (esim. Goodman, 2020). Uskonnosta etsitään merkitystä, hallinnantunnetta ja lohdullista jumalasuhdetta (Pargament ym., 2013:563). Suomessa kirkot ovat tarjonneet koronakriisin aikana monenlaista apua ( $\mathrm{Sa}-$ lomäki, 2020c:2). Luterilainen kirkko on halunnut välittää viestiä, että sen työntekijät ovat kaikkien ihmisten saatavilla, vaikka seurakuntien toimintaa on jouduttu supistamaan. Kirkon kriisiapu on kohdistettu kaikille, ei ainoastaan kirkon jäsenille. (Kirkon toiminta pandemian aikana, evl.fi, 2021.) Ortodoksinen kirkko puolestaan on reagoinut koronakriisiin muun muassa avaamalla maaliskuussa 2020 palvelevan puhelimen ja chatin (Ortodoksisen 
kirkon palveleva puhelin, 2020; Keskustelutoiminto kirkon etusivulle, 2020).

Uskonnollisten yhteisöjen toimintaympäristö muuttui radikaalisti keväällä 2020, kun ne rajoittivat toimintaansa osallistumista. Kirkkojen toiminta vietiin maaliskuun puolivälistä 2020 alkaen pääasiallisesti verkkoon muun muassa jumalanpalveluksia striimaamalla (Arkkipiispan ohjeet, 2020; Jumalanpalvelukset siirtyvät nettiin, 2020; Salomäki, 2020b:8). Erityisesti luterilaisen kirkon rooli kriisitoimijana tunnustettiin myös valtionhallinnossa. Tiede- ja kulttuuriministeri Annika Saarikko totesi syksyllä 2020 puheessaan kirkolliskokoukselle, että "Henkisen kriisinkestävyyden turvaamiseen kuuluu myös hengellisen toiminnan edellytysten turvaaminen. Mitä suurempia uhkia ja kriisejä koemme, sitä suurempi merkitys henkisellä hyvinvoinnilla ja hengellisellä toiminnalla on”(Toivanen, 2020).

Jumalanpalvelusten striimaaminen mahdollisti kirkkojen toiminnan saavutettavuuden normaalioloista poikkeavassa tilanteessa. Sekä luterilaisen että ortodoksisen kirkon etäyhteyksin toteutetut jumalanpalvelukset keräsivät maalis-toukokuussa 2020 moninkertaisesti enemmän osallistujia kuin paikan päällä vietetyt jumalanpalvelukset vastaavana ajankohtana edellisvuonna. Pääsiäistä edeltävinä viikkoina osallistujamäärät olivat enimmillään yli kymmenkertaisia vuodentakaiseen verrattuna. Viikoittaiset osallistujamäärät pysyivät edellisvuotta korkeampina koko vuoden 2020. (Kirkon tutkimuskeskus, 2021; Hattunen, 2021.) Osallistumismäärän kasvu kertoo etäyhteyksin seurattavien tilaisuuksien kysynnän tarpeesta. Huhti-toukokuussa 2020 tehdyn kyselyn mukaan puolet suomalaisista piti tärkeänä, että jumalanpalveluksiin pystyi osallistumaan verkon välityksellä. Suomalaisista 14 prosenttia oli tuolloin seurannut jumalanpalveluksia verkosta. (Salomäki, 2020a:11-12.)

Tässä artikkelissa tarkastelemme Suomen ortodoksisen kirkon ja Suomen evankelis-luterilaisen kirkon striimattuihin jumalanpalveluksiin osallistuneiden ihmisten kokemuksia hengellisestä yhteydestä ja muutoksista omassa hengellisyydessään COVID-19-pandemian ensimmäisen aallon aikana. Hengellisen yhteyden termillä tarkoitamme yhteyttä, joka muodostuu erityisesti kolmesta osa-alueesta: seurakunta-, ehtoollis- ja rukousyhteydestä. Jatkossa käytämme myös termiä "yhteys", kun viittaamme hengelliseen yhteyteen. Kysymme, millainen oli kyselyyn vastanneiden suomalaisten kokemus hengellisestä yhteydestä virtuaalisessa liturgisessa toimintaympäristössä sekä miten he sanoittivat pandemiatilanteen vaikutusta hengellisyyteensä pandemian alkuvaiheessa. Kysymyksenasettelu perustuu edellä todettuun suoma- 
laisten kirkkoon kohdistamaan arvostukseen kriisitilanteissa ja kirkollisen toiminnan saavutettavuuteen poikkeusoloissa osana yhteiskunnan henkistä kriisinkestävyyttä. Käsittelemämme yhteyden ulottuvuudet valottavat lähemmin kriisinkestävyyden ilmiötä yksilöiden ja yhteisöjen vuorovaikutuksessa kirkkojen toiminta-alueella. Tutkimuksemme kytkeytyy yleiseen hengellisyyden terveyttä edistävään vaikutukseen, jonka merkitystä avaamme seuraavaksi lyhyesti.

Kirkkojen toiminnassa korostunut kansalaisten henkisen kriisinkestävyyden tukeminen on yhteydessä ihmisen kokonaisvaltaiseen hyvinvointiin. Maailman terveysjärjestö WHO on vuodesta 1984 suositellut hengellisen hyvinvoinnin (spiritual well-being) sisällyttämistä terveyden käsitteeseen neljänneksi osa-alueeksi terveyden fyysisen, henkisen ja sosiaalisen ulottuvuuden rinnalle. Hengellinen terveys sisältää ajatukset, uskon, arvot ja etiikan (Chirico, 2016). Suomessa terveyden hengellistä ulottuvuutta on käsitteellistetty käsiteparilla "henkinen ja hengellinen terveys". Sillä tarkoitetaan yksilöllistä ja yhteisöllistä tasapainoa, joka rakentuu ymmärrykselle elämän perusarvoista ja merkityksestä sekä pohditulle suhteelle uskon kysymyksiin ja omaan vakaumukseen. Henkisyys ja hengellisyys ovat osa maailmankatsomusta, ja ne liittyvät ihmisen kokonaishyvinvointiin, terveyteen ja elämänlaatuun (Hanhirova \& Aalto, 2009; Karvinen, 2012; Louheranta ym., 2016).

Hengellisellä hyvinvoinnilla on yhteys henkiseen kriisinkestävyyteen. Esimerkiksi kyky ymmärtää tapahtumien merkityksiä ja pohtia asioita yksin, elämän tarkoituksen tavoittaminen sekä toisten hyvinvoinnista välittäminen ovat kriisitilanteessa korostuvia merkkejä hengellisestä hyvinvoinnista. Hengellinen hyvinvointi tarjoaa välineitä käsitellä erilaisia yllättäviä ja vaikeita tilanteita sekä auttaa pääsemään niistä yli. (esim. Fehring ym., 1997; Heintzman \& Mannell, 2003; Unterrainer ym., 2010; Fisher, 2011; Unterrainer ym., 2013; Amjad \& Bokharey, 2014; Gonzalez, 2014). Kansainvälisen tutkimuksen mukaan uskonnollisesti identifioituneet ihmiset ovat kokeneet elämän merkityksellisemmäksi koronakriisin aikana kuin uskonnottomat ihmiset (Saarelainen, 2020). Suomalaiset pitävät kirkon läsnäoloa tärkeänä kollektiivisissa kriiseissä, ja myös uskonnollisesti passiiviset ihmiset arvostavat kirkon tarjoamaa kriisiapua (Karppanen, 2007: 82, 91.) Koronakriisin alkuvaiheessa puolet suomalaisista piti tärkeänä kirkon tarjoamaa henkistä ja hengellistä tukea (Salomäki, 2020a; Salomäki, 2020c). Hengellisen yhteyden yhteiskunnallinen ja sosiaalinen relevanssi koronapandemian aikana näyttää 
ilmenevän etenkin seurakuntayhteyden ja mahdollisesti myös rukousyhteyden merkityksissä.

\section{TUTKIMUKSEN AINEISTO JA MENETELMÄ}

Tämän artikkelin tutkimusaineisto muodostuu seurakuntalaisaineistosta, joka kerättiin kahdella kyselylomakkeella koronapandemian ensimmäisen aallon aikana keväällä ja kesällä 2020. Kysely toteutettiin kahden julkisoikeudellisesti erityisessä ja keskenään rinnasteisessa asemassa Suomessa olevan kirkon piirissä. Luterilaisella ja ortodoksisella kirkolla on juridisesta ja yhteiskunnallisesta asemastaan johtuen näkyvä uskonnollisen toimijan rooli. Kyseisten kirkkojen nopea reagointi viranomaisten päätöksiin ja suosituksiin, toimet kansalaisten hengellisestä ja sosiaalisesta hyvinvoinnista huolehtimisesta poikkeusoloissa sekä toimenpiteistä viestiminen ja niistä uutisointi muodostivat perusteen kohdistaa kysely juuri niiden toiminnassa mukana oleville, kun tavoitteena oli selvittää uskonnollisten yhteisöjen toiminnassa mukana olleiden kokemuksia koronakriisin vaikutuksista. Tutkimusaineistomme muodostuu yhteensä 555 suomalaisen vastauksista. Suurin osa vastaajista on ortodoksisen tai luterilaisen kirkon jäseniä: heistä 59 prosenttia kuuluu ortodoksiseen kirkkoon ja 34 prosenttia luterilaiseen kirkkoon. Näihin kirkkoihin kuulumattomia on seitsemän prosenttia vastaajista.

Ensimmäinen kysely suunnattiin Suomen ortodoksisen kirkon striimattuihin jumalanpalveluksiin osallistuneille. Osallistumiskutsu ja linkki sähköiseen kyselylomakkeeseen julkaistiin Suomen ortodoksisen kirkon verkkosivuilla, ja niitä jaettiin jonkin verran sosiaalisessa mediassa. Vastauksia kyselyyn tuli 330 henkilöltä, ja vastaajista 98 prosenttia ilmoitti kuuluvansa ortodoksiseen kirkkoon. Selkeä enemmistö kyselyyn vastanneista oli yli 40-vuotiaita (83\%). Vastaajien maantieteellistä jakaumaa selvitettiin hiippakunnittain: vastaajista yli puolet (57\%) ilmoitti olevansa Helsingin hiippakunnan, 28 prosenttia Kuopion ja Karjalan hiippakunnan ja 15 prosenttia Oulun hiippakunnan alueelta. Toinen kysely suunnattiin Suomen evankelis-luterilaisen kirkon toimintaan osallistuneille suomalaisille. Kutsua tutkimukseen osallistumiseen jaettiin tutkijoiden kotiyliopiston internetsivuilla sekä sosiaalisen median kautta eri verkostoissa. Kyselyyn vastasi 225 suomalaista, joista suurin osa (85 \%) on Suomen evankelis-luterilaisen kirkon jäseniä. Noin joka kymmenes (12 \%) vastaaja kertoi, ettei ole evankelisluterilaisen kirkon jäsen. 
Vastaajia oli kaikista maakunnista, eniten Uudeltamaalta (21\%) ja vähiten Ahvenanmaalta $(0,4 \%)$.

Vaikka ortodoksisen kirkon piirissä jaettuun kyselyyn kerättiin vastauksia aiemmin ja lyhyemmän aikaa kuin luterilaisen kirkon kyselyyn, sen vastaajamäärä oli merkittävästi suurempi kuin luterilaisen kirkon piirissä jaetun kyselyn. Eroa selittävät kyselyjen jakamisen erilaiset alustat sekä mahdollisesti myös kyselyn merkitykset eri kirkkokuntien vastaajille. Ortodoksisen kirkon verkkosivut ovat keskeisin ortodoksisen kirkon tiedotuskanava, jota seurataan aktiivisesti myös sivulta löytyvän jumalanpalveluskalenterin ja päivittäisten liturgisten ohjeiden vuoksi. Toisaalta eroa voivat selittää myös ne nimenomaiset tekijät, joita olemme tutkineet: esimerkiksi jollakin tapaa kipeäksi tai vaillinaiseksi koettu seurakuntayhteys on voinut luoda motivaation kyselyyn vastaamiselle. Palaamme johtopäätöksissä tarkemmin vastaajajoukkojen eroavaisuuksiin ja mahdolliseen vastausmotivaatioon.

Suurin osa tutkimukseemme vastanneista oli yli 40-vuotiaita. Vastaajat on ryhmitelty iän mukaan seuraavassa taulukossa:

\begin{tabular}{|l|l|l|l|}
\hline Ikä & $\begin{array}{l}\text { Ortodoksikyselyn } \\
\text { vastaajat }(\mathrm{N}=330)\end{array}$ & $\begin{array}{l}\text { Luterilaiskyselyn } \\
\text { vastaajat }(\mathrm{N}=225)\end{array}$ & $\begin{array}{l}\text { Kaikki vastanneet } \\
(\mathrm{N}=555)\end{array}$ \\
\hline Alle 25 v. & $3 \%$ & $15 \%$ & $8 \%$ \\
\hline $25-40$ v. & $14 \%$ & $28 \%$ & $20 \%$ \\
\hline $41-55$ v. & $32 \%$ & $22 \%$ & $28 \%$ \\
\hline $56-69$ v. & $37 \%$ & $28 \%$ & $33 \%$ \\
\hline 70 v. tai yli & $14 \%$ & $7 \%$ & $11 \%$ \\
\hline
\end{tabular}

Taulukko 1. Vastaajien ikäjakauma.

Huomattava osa kaikista vastaajista kertoi osallistuneensa aktiivisesti seurakunnan jumalanpalveluksiin ennen korona-aikaa. Yli 80 prosenttia ortodoksiaineiston vastaajista ilmoitti osallistuneensa jumalanpalveluksiin vähintään kerran kuukaudessa ja 38 prosenttia keskimäärin viikoittain. Harvoin tai ei lainkaan eli 0-5 kertaa vuodessa palveluksiin osallistuneita oli noin kuudennes vastaajista (16 \%). Myös luterilaisaineiston vastaajat osallistuvat kirkon toimintaan keskivertosuomalaisia aktiivisemmin. Lähes puolet (46 \%) kyselyyn vastanneista ilmoitti osallistuvansa jumalanpalvelukseen normaalioloissa 
kerran viikossa tai useammin. Ainoastaan 10 prosenttia vastaajista ilmoitti osallistuvansa jumalanpalveluksiin harvemmin kuin kerran vuodessa.

Molemmat kyselylomakkeet sisälsivät suljettuja ja avoimia kysymyksiä. Lomakkeiden kysymykset oli jaoteltu seuraavien teemojen alle: osallistuminen jumalanpalveluksiin, kokemukset striimatuista seurakunnan tilaisuuksista, ehtoollinen ja koronaepidemian vaikutus rukouselämään. Ortodokseille suunnatussa kyselylomakkeessa kysyttiin lisäksi ehtoollista laajemmin sakramentteihin osallistumisesta sekä pääsiäisen viettämisestä. Lomakkeet olivat rakenteeltaan samanlaiset, mutta kysymysten muotoiluissa oli joitakin kirkkokuntakohtaisia eroja. Tässä artikkelissa tarkastelemme suljettuihin ja avoimiin kysymyksiin tulleita vastauksia yhteyden ja hengellisyydessä tapahtuneiden muutosten näkökulmasta. Monivalintakysymyksiin tulleista vastauksista olemme laskeneet suorat prosenttijakaumat. Pääpaino on avoimiin kysymyksiin tulleiden vastausten laadullisessa analyysissä. Viittaamme vastaajien suoriin sitaatteihin seuraavilla koodeilla: $\mathrm{L}=$ luterilaisaineisto ja $\mathrm{O}=$ ortodoksiaineisto.

Tutkimusmenetelmiämme ovat lähiluku (ks. esim. Federico, 2015) ja aineistolähtöinen laadullinen sisällönanalyysi (Kallinen \& Kinnunen, s.a.). Olemme teemoitelleet aineiston (ks. esim. Eskola \& Suoranta, 2001:174180; Silverman, 2006:159) ja analysoineet teemojen sisältöjä yhteistyössä koko tutkimusryhmämme kesken. Vaikka kyseessä ei ole varsinaisesti vertaileva tutkimus, tuomme ortodoksi- ja luterilaisaineistojen eroavaisuuksia esille niiltä osin kuin aineisto sen luontevasti ja luotettavasti mahdollistaa. Artikkelin ensimmäisessä tulosluvussa tarkastelemme sitä, millainen oli vastaajien kokemus hengellisestä yhteydestä koronapandemian ensimmäisen aallon aikana. Toisessa tulosluvussa tutkimme, millä tavoin vastaajat sanoittivat hengellisyydessään tapahtuneita muutoksia poikkeusolojen aikana vastatessaan uskoon ja rukouselämään liittyviin kysymyksiin.

\section{Hengellisen yhteyden kokemukset poikkeusoloissa}

Koronapandemian aikana kirkot ovat järjestäneet kaikille avoimia tilaisuuksia, joihin on ollut mahdollista osallistua verkkovälitteisesti. Seurakuntayhteisöjen toimintaan osallistuminen etäyhteyksien varassa näkyy aineistossamme hengellisen yhteyden kokemuksen muutoksina, erityisesti heikentymisenä, mutta myös uudenlaisten yhteyksien syntymisenä. 


\section{Kokemukset heikentyneestä yhteydestä}

Huomattava osa tutkimukseemme vastanneista koki poikkeusolojen vaikuttaneen haitallisesti kokemukseensa yhteydestä seurakuntaan ja toisiin seurakuntalaisiin. Luterilaisaineiston vastaajista jopa 59 prosenttia koki seurakuntayhteyden heikentyneen pandemian ensimmäisen aallon aikana. Ortodoksiaineiston vastaajilla seurakunta-, ehtoollis- ja rukousyhteyden heikentyminen näyttäytyivät erityisen kiinteästi toisiinsa limittyneinä. Osa heistä koki seurakuntayhteyden jopa katkenneen kokonaan, kun fyysiset kokoontumiset seurakunnissa jäivät tauolle tai vaihtuivat verkkovälitteisiksi.

Ortodoksiaineistossa 16 prosenttia kertoi tilanteen vaikuttaneen kielteisesti asennoitumiseensa kirkkoa kohtaan. Kirkkosuhteeseen kielteisesti vaikuttaneet koronatilanteesta juontuvat syyt olivat kirkkojen sulkeminen kirkkokansalta, kirkon taholta koettu välinpitämättömyys seurakuntalaisia tai tiettyjä ryhmiä (lapsiperheet, nuoret, kirkkoon liittyjät) kohtaan sekä oma laiskistuminen ja kirkollisesta elämästä vieraantuminen. Usea etääntymisestä kertonut vastaaja pohti, tuleeko korona-aika näkymään kirkollisen aktiivisuuden yleisenä vähentymisenä ja kirkosta eroamisina tulevaisuudessa. 12 prosenttia ortodoksiaineiston vastaajista kuvasi kirkkosuhteeseensa vaikuttaneita myönteisiä ja kielteisiä piirteitä, mutta eivät kuitenkaan kuvanneet suhteen muuttuneen selkeästi kumpaankaan suuntaan.

Molempien aineistojen heikentynyttä yhteyttä kokeneille jumalanpalvelus oli rakas tilaisuus, johon he normaalioloissa säännöllisesti osallistuivat. Vastaajat kuvailivat lämpimästi kotikirkkonsa tunnelmaa, kirkkoon menemistä, yhdessä laulamista sekä tuttujen ihmisten tapaamista. Jumalanpalvelukseen osallistumiseen liittyi vahvasti turvallinen ja myönteinen tunnekokemus, joka oli pandemian aikana järkkynyt. Seurakuntayhteyden merkitys oli saattanut jopa kirkastua poikkeusolojen myötä, mistä kertoi muun muassa vastaaja O293:"Huomaan heikentyväni ilman kirkon jatkuvaa ja vahvaa fyysistä läsnäoloa elämässäni. En uskonut olevani näin yhteisöllinen.” Kansainvälisten tutkimusten mukaan yhteenkuuluvuuden kokemukset kollektiivisen trauman aikana vaihtelevat ihmisillä. Joka tapauksessa inhimillinen hyvinvointi on yleensä vahvasti kytköksissä ympärillä oleviin ihmisiin, kuten myös oma aineistomme osoittaa. (Baumeister \& Leary 1995; Voicu ym. 2020:12,14.)

Aineistostamme esille nousseet havainnot jumalanpalvelus- ja ehtoollisyhteyden tärkeyden ja yhteisöllisyyden heikkenemisen kokemuksesta ko- 
rona-aikana ovat yhteydessä vastaajien kokemuksiin striimatuista jumalanpalveluksista. Suurin osa (73 \%) kaikista tutkimukseemme vastanneista oli osallistunut striimattuihin jumalanpalveluksiin. Ortodoksiaineisto kerättiin kesäkuussa, jolloin jumalanpalveluksia oli striimattu vastausajankohdasta riippuen 11-14 viikkoa. Luterilaisaineisto kerättiin kesäkuun ja syyskuun välillä, joten striimattuja jumalanpalveluksia oli ehtinyt olla vielä huomattavasti enemmän. Luterilaisaineistossa 62 prosenttia vastanneista kertoi osallistuneensa striimattuihin jumalanpalveluksiin vähintään neljä kertaa. Ortodoksisen kirkon aineistossa vastaava luku oli peräti 80 prosenttia. Ainoastaan 4 prosenttia ortodoksisen kirkon kyselyyn vastanneista ei ollut osallistunut yhteenkään striimattuun jumalanpalvelukseen, kun taas luterilaisen kirkon aineistossa heitä oli 16 prosenttia. On mahdollista, että tulokset viittaavat ortodoksien vahvempaan seurakuntayhteyteen sekä oman hengellisen- ja rukouselämän voimakkaampaan kytkeytymiseen yhteisölliseen jumalanpalvelukseen.

Molempien aineistojen vastauksista käy voimakkaasti ilmi, että kaipuu toisten ihmisten yhteyteen konkretisoitui striimattuja jumalanpalveluksia seuratessa. Ihmiset kokivat outona sen, etteivät voineet ottaa kontaktia muihin jumalanpalvelukseen osallistuviin. Esimerkiksi vastaaja L156 sanoittaa kokemustaan näin: "Omassa olohuoneessa nojatuolissa istuessa ei oikein tule kirkkotunnelmaa. Tyhjä parempi, mutta ei hyvä. On sellaisia tuttuja, joita tapaa lähinnä kirkossa jumalanpalvelusten yhteydessä. [...]” Lisäksi yksin kotona yhtyminen seurakunnan osuuksiin, kuten virsien laulamiseen ja rukouksiin, tuntui monen vastaajan mielestä erikoiselta.

Useissa vastauksissa kokemusta striimattujen palvelusten seuraamisesta peilattiin fyysiseen kirkossa käyntiin. Vastaajat sanoittivat kirkossa jumalanpalvelukseen osallistumisen kokonaisvaltaisen, kehollisen kokemisen tärkeyttä. Striimattua palvelusta seurattaessa jumalanpalveluskokemuksesta puuttuivat "kehollisuus, halaaminen, sosiaalinen oleminen" (L35) sekä "[kirkko]tilan kokemus", "ehtoollisleivän ja viinin tuoksu ja maku" ja "papin katse" (L109). Monipuolisten aistikokemusten puute tuli esille kaipauksen kokemuksissa:

Ikävöin kovasti pääsyä palveluksiin fyysisesti, ikävöin kaikkia seurakuntalaisia, kaikkia tuntemuksia mitä kirkko rakennuksena antaa, kauniita ikoneja, tuohusten ja suitsukkeiden tuoksua. Kuoron kaunista laulua ja turvallisia ja tuttuja pappeja, kaikkea kaipaan (O103). 
Vastaajat harmittelivat myös muun muassa kättelyn, poskisuudelmien vaihtamisen, papilta siunauksen saamisen ja kirkkokahveille osallistumisen puuttumista. Esimerkiksi L174 kuvasi kokemustaan striimattuihin jumalanpalveluksiin osallistumisesta yhteyden näkökulmasta seuraavasti:"Ei striimaus korvaa aitoa jumalanpalvelusta, Jumalan perheväen suurta juhlaa kirkossa. Siinä on mukana joka aistilla, tapaa muita seurakuntalaisia, voi osallistua ehtoolliselle, kätellä, halata ja parhaassa tapauksessa jäädä vielä kirkkokahveille.”(L174) Myös ortodoksiaineistossa summattiin samankaltaista kokemusta: "Nettipalvelukset ovat hyvä yritys mutta eivät yhtään sama asia" (O314).

Yhteyden heikentymistä kokeneet vastaajat molemmissa aineistoissa kaipasivat erityisesti ehtoollisyhteyttä. He kuvailivat ehtoollisesta osattomaksi jäämistä kipeäksi ja harmilliseksi kokemukseksi. Tässä suhteessa aineiston tulokset poikkeavat varsin merkittävästikin aiemmasta, luterilaisen kirkon kirkkoherrojen parissa tehdystä tutkimuksesta, jonka mukaan kirkkoherrat kokivat poikkeusoloissa vahvistunutta yhteyttä seurakuntalaisiin erityisesti silloin, kun seurakunnassa ei järjestetty ehtoollisjumalanpalveluksia. Tuolloin kirkkoherrojen yhteyden kokemus syntyi jaetusta kaipauksesta ehtoollisen sakramenttiin. (Kallatsa \& Mikkola, 2020:19-20.) Erilaiset uskonnolliset rituaalit ylläpitävät ihmisten hyvinvointia vaikeissa tilanteissa. Uskonnolliseen rituaaliin osallistuessaan ihminen tiedostaa jotain merkittävää tapahtuvan, mikä auttaa häntä asettamaan vallitsevan tilanteen myönteisempään asiayhteyteen. (Goodman, 2020; Pargament, 2007:100.) Ehtoollisella näyttäisikin olevan tärkeä rituaalinen ulottuvuus, jota ei voi korvata fyysisen seurakuntayhteyden puuttuessa samalla tavoin kuin jumalanpalveluksen muita osia.

Erityisesti luterilaisaineistosta käy ilmi, että jumalanpalvelusten toteuttajien sanavalinnat vahvistivat tai heikensivät yhteyden kokemusta seurakuntalaisten keskuudessa. Vastaajien mukaan pappien tulisi huomioida striimauksen välityksellä jumalanpalvelukseen osallistuvat erityisellä tavalla: "Osassa on puhuteltu kuin olisin katsoja enkä osallistuja ja se on luotaantyöntävää." (L23). Lisäksi muutama vastaaja niin ortodoksisessa kuin luterilaisessa aineistossa nosti esille, että striimauksen tekniset heikkoudet heikensivät yhteyden kokemusta. Kaiken kaikkiaan hengellisen yhteyden heikentymistä kokeneet vastaajat kokivat jääneensä tutun seurakuntayhteyden ulkopuolelle. Vastaajat kirjoittivat, että striimattuja jumalanpalveluksia voi katsella, mutta niihin ei voi osallistua: "En ole pystynyt leikkimään olevani kirkossa. En sanoisi osallistuneeni, vaan nimenomaan olen katsellut"(O210). Siirtyminen osallistujasta katsojaksi oli monelle vastaajalle kipeä tunnekokemus, ja aiheutti erillisyy- 
den ja ulkopuolisuuden tunteita. Vaikka useimmat vastaajat olivat tyytyväisiä striimauksen tarjoamaan mahdollisuuteen päästä osalliseksi jumalanpalveluksesta, vastauksissa tuotiin toistuvasti esille, että striimatut palvelukset eivät yksinkertaisesti pysty välittämään kokonaisvaltaista jumalanpalvelukseen osallistumisen kokemusta.

\section{Kokemukset yhteyden ja osallisuuden voimistumisesta}

Aineistomme osoittaa, että koronatilanteen vaikutus hengellisen yhteyden ja osallisuuden kokemukseen ei ole yksinomaan kielteistä. Ortodoksiaineistossa suurimman vastaajaryhmän (46 \%) muodostivatkin ne, joiden suhtautumiseen kirkkoa kohtaan tilanne oli vaikuttanut myönteisesti. Heidän lisäkseen vajaa viidennes vastaajista (17\%) kertoi, että kirkkosuhde oli pysynyt ennallaan. Myönteisyys ilmeni esimerkiksi kirkon yhteyteen koetun kaipauksen heräämisenä, tyytyväisyytenä kirkon tekemiä koronatoimia kohtaan, poikkeusoloissa tehdyn seurakuntatyön arvostamisena ja osallisuuden vahvistumisena. Viimeksi mainittua kuvattiin niin henkisenä kokemuksena kuin käytännön toimina, esimerkiksi korona-ajan uusiin toimintamuotoihin kuten striimauksiin osallistumisena.

Mahdollisuus striimattujen palvelusten seuraamiseen oli monen ortodoksivastaajan mukaan yhteydessä rukouselämän vilkastumiseen sekä yhteisöllisyyden ja osallisuuden uudenlaiseen kokemiseen: noin 80 prosenttia ortodoksisen aineiston vastaajista oli osallistunut myös muiden kuin kotiseurakuntansa striimattuihin palveluksiin. Mahdollisuus "vierailla" muissa ortodoksisissa seurakunnissa Suomessa ja ulkomailla toi virkistystä, lisäsi rukousaktiivisuutta ja vahvisti ortodoksista identiteettiä. Seurattavan palveluksen valinnan perusteina vastauksissa mainittiin esimerkiksi halu tutustua uusiin pyhäköihin, toteutuskanava, ajankohta ja toimituskieli.

Luterilaisaineiston vastaajista pieni osa (7 \%) kertoi kokeneensa vahvistunutta hengellistä yhteyttä pandemian aiheuttamien poikkeusolojen aikana. Vahvistuneen yhteyden kokemukset liittyivät kokemuksiin yhteydestä aikaisempaa laajempaan kristikuntaan sekä entistä aktiivisempaan osallistumiseen jumalanpalveluksiin. Muutamat vastaajat olivat osallistuneet suuriin nettirukouspiireihin, jotka olivat koonneet osallistujia ympäri maailmaa. Tätä kuvasi esimerkiksi L56, joka kertoi rukoilemisesta "ympäri Suomea skypessä, zoomissa ja teamsissa" ja parhaimmillaan "yli 700 henkilöä eri puolilta maailmaa" tavoit- 
taneesta rukousringistä. Osa taas koki pystyneensä osallistumaan aikaisempaa aktiivisemmin useiden seurakuntien toimintaan etäyhteyksien ansiosta.

Striimatut palvelukset mahdollistivat vierailun myös eri kirkkojen ja uskonnollisten yhteisöjen jumalanpalveluksissa. Ortodoksisen kirkon palveluksia seuranneista 12 prosenttia oli seurannut muiden kirkkojen lähetyksiä, lähinnä luterilaisia jumalanpalveluksia. Huomattavasti useampi luterilaisaineiston vastaaja (32\%) oli osallistunut muiden kuin luterilaisen kirkon tilaisuuksiin internetin välityksellä. Näistä useimmin vastauksissa mainittiin ortodoksinen kirkko ja helluntaiseurakunnan, vapaakirkon sekä Taizé-yhteisön tilaisuudet. Ortodoksiaineistossa vastaajien vähäistä osallistumista muiden kirkkokuntien palveluksiin voidaan pitää yllättävänä, sillä suomalaiset ortodoksit elävät luterilaisia useammin ekumeenisissa avioliitoissa ja perheissä, minkä voisi olettaa lisäävän osallistumista myös muihin kuin ortodoksisiin palveluksiin.

Siinä missä osa seurakuntalaisista koki striimauksen vähemmän yhteisölliseksi kuin fyysisen yhteen kokoontumisen, joidenkin vastaajien mielestä striimauksen välityksellä kotiin tullut jumalanpalvelus tuntui yhteisöllisemmältä. Esimerkiksi L179 kertoi yllättyneensä siitä,"miten luonnolliselta tuntui seurata striimattua lähetystä ja miten striimauskin välitti tunnelman ja tuli, ristiriitaista kyllä, tietyllä tavalla lähemmäksi kuin kirkon penkissä istuessa”. Kokemukseen vaikuttivat hänen mukaansa muun muassa striimauksen hyvät kuvakulmat. Striimatut palvelukset saattoivat myös lisätä perheen hengellistä yhteisöllisyyttä. Ortodoksiaineistossa 38 prosenttia vastaajista oli seurannut palveluksia perheenjäsenten kanssa, ja perheet ja ystävät saattoivat "kokoontua" samaan striimattuun palvelukseen eri puolilta Suomea. Kirkon tutkimuskeskuksen tekemän tutkimuksen mukaan henkilökohtaisesti merkityksellisten paikallisyhteisöjen jumalanpalvelukset kiinnostivat ihmisiä pandemian aikana enemmän kuin tilaisuudet, joiden järjestäjään ei ole aiempaa kontaktia (Salomäki, 2021:12-13). Tämä näkyy sekä luterilaisen että ortodoksisen kirkon palveluksia seuranneiden vastauksissa, joiden perusteella eniten ja mieluiten osallistuttiin tutuksi koetun kotiseurakunnan ja tuttujen pappien toimittamiin palveluksiin.

Hengellisen yhteyden näkökulmasta kokemus autonomiasta nousi olennaiseksi tekijäksi erityisesti luterilaisaineiston avoimissa vastauksissa. Autonomialla tarkoitetaan tässä yhteydessä ihmisen vapautta valita, millaiset olosuhteet hän itse luo jumalanpalvelukseen osallistumiselle pandemian ai- 
heuttamissa poikkeusoloissa. Lähes 40 prosenttia luterilaisaineiston vastaajista kommentoi kokemuksiaan seurakuntien toiminnasta poikkeusaikana autonomian näkökulmasta. Autonomian ilmiö tuli esiin myös osassa ortodoksiaineiston avoimia vastauksia. Autonomian merkitys korostui erityisellä tavalla niiden vastaajien kohdalla, jotka etäisyyksien, sairauden, vamman tai seurakuntayhteyden puuttumisen takia eivät normaalioloissa ole päässeet kirkkoon. Striimattujen palvelusten myötä heille tarjoutui ensimmäistä kertaa muiden kanssa tasaveroinen mahdollisuus olla jumalanpalvelusyhteydessä.

Moni vahvistunutta autonomiaa kokenut tunsi jumalanpalveluksiin osallistumisen aikaisempaa vaivattomammaksi. Aineistossamme toistuivat kuvaukset leppoisasta sunnuntaiaamusta kiireettömästi kahvimuki kädessä. Kotona jumalanpalvelukseen osallistuessaan ihminen on omassa henkilökohtaisessa tilassaan, mikä näyttäytyi positiivisena, myös osallisuutta vahvistavana asiana vahvistunutta autonomiaa kokeneilla. L110 ja O159 sanoittivat:

Samalla kun kuuntelee tilaisuuksia voi paremmin, [...] levollisemmin, rentoutuneemmin, intensiivisemmin, monipuolisemmin, käytännöllisemmin, helpommin ja luontevammin olla oma itsensä. Samalla on ollut mukavampi laulaa mukana, tutkia virsikirjan lauluja ja Raamattua häiriöttömämmin kuin fyysisesti paikallaollen, jossa huomio ajautuu helpommin muualle ja joutuu olemaan tarkkaavaisempi kuunnellessaan ja keskittyessään julkiseen tilaisuuteen. (L110)

Neulon, virkkaan ja teen muita käsityötä. Silitän kissoja ja juon aamukahvit. Myös luterilainen mieheni saa kirkkotunnelmaa ja pitää siitä. (O159)

Useat molempien kirkkojen tilaisuuksiin osallistuneet kokivat arvokkaaksi, turvalliseksi ja luontevaksi osallistua jumalanpalvelukseen kotona. Aineisto kertoo osallistumistapojen kirjavuudesta. Kun yksi kertoi pukeutuvansa striimiä varten kuin kirkkoon mennessä ja olevansa "kotona ikäänkuin kirkoss[a]" (O17), toinen kertoi heräävänsä juuri ennen jumalanpalvelusta ja osallistuvansa yöpuku päällä (L3) ja kolmas iloitsi siitä, että kotoa käsin hänkin on nyt "voinut veisata mukana (mikä livenä osallistuessani ei ole mahdollista, kun en kelpaa kuoroon ja seurakunta ei juurikaan saa veisata)" (O47). Useissa vastauksissa myös mainittiin, että striimattuihin jumalanpalveluksiin osallistuminen mahdollisti esimerkiksi kotitöiden (siivoaminen, ruoanlaitto, lastenhoito) 
tai käsitöiden tekemisen samaan aikaan. Yli puolet ortodoksisia palveluksia seuranneista kertoi tehneensä samalla jotakin muuta. Ortodoksisia palveluksia seurattiin myös makoillen tai istuen, mikä poikkesi normaalista kirkossa seisten osallistumisesta. Autonomian kokemusta lisäsi molempien seurakuntalaisaineistojen perusteella myös mahdollisuus katsoa jumalanpalvelus silloin, kun itselle parhaiten sopi.

Myönteinen kokemus vahvistuneesta autonomiasta näytti siten monen vastaajan mielessä vahvistavan myös kokemusta osallisuudesta ja hengellisestä yhteydestä. Havainto on linjassa esimerkiksi sen aiemman tutkimuksen kanssa, jonka mukaan hallinnan tunteen tavoittelu on olennainen osa uskonnollista merkityksenetsintää (Pargament ym., 2013:563). Vahvistunutta autonomiaa kokeneilla mahdollisuus osallistua kirkon toimintaan kotoa käsin synnytti usein kokemuksen aidommasta omana itsenään osallistumisesta ja siten kokemuksen oman seurakuntayhteyden aiempaa omaehtoisemmasta hallinnasta.

Myös autonomiaan liittyvissä vastauksissa tuli toisaalta esille päinvastainen kokemus, jota väritti itsemääräämisoikeuden ja omaehtoisuuden heikentyminen. Osa vastaajista koki, että heillä oli aiempaa vähemmän omaehtoisia mahdollisuuksia vaikuttaa osallistumiseensa, koska kirkkoon ei saanut poikkeusolojen aikana mennä. Autonomian heikentyminen liittyi osalla vastaajista myös verkkovälitteisten jumalanpalvelusten teknisiin ratkaisuihin, kuten siihen, että kuvaajan valitessa kuvakulmat palvelukseen osallistuvana tai sitä seuraavana ei saanut päättää, mihin katseensa kirkkotilassa suuntasi (näin esim. L133). Palveluksen seuraamisen nivoutuessa arkielämään se jäi autonomian heikentymistä kokeneiden vastaajien näkökulmasta taustalle, ja osallisuuden kokemus oli heidän näkökulmastaan myös siksi vähäinen. Kokemus pakosta viettää palvelusta poikkeavassa ympäristössä fyysisen kirkkotilan puuttuessa vaikutti siten osallistumiskokemukseen ja yhteyden kokemiseen heikentävästi.

\section{Muutokset hengellisyydessä koronakriisin aikana}

Uskonnolliset ihmiset hyötyvät uskonnollisista selviytymiskeinoista poikkeuksellisissa tilanteissa yleensä kaikista eniten (Hood ym., 2018:488). Tutkimuksemme vastaajajoukko koostuu suurimmaksi osaksi ihmisistä, jotka osallistuvat normaalioloissa säännöllisesti luterilaisen tai ortodoksisen kirkon toimintaan. Tässä luvussa analysoimme muutoksia vastaajien hengellisyydes- 
sä ortodoksi- ja luterilaisaineiston pohjalta. Tarkastelemme teemaa uskon ja rukouselämän näkökulmista.

Noin puolet (46 \%) luterilaiseen kyselyyn osallistuneista koki pandemian ensimmäisen aallon vaikuttaneen heidän uskoonsa ja hengellisyyteensä, kun taas vastaavasti hieman yli puolet (54\%) vastaajista koki, ettei pandemialla ollut vaikutuksia uskoon ja hengellisyyteen. Suurin osa (64 \%) niistä vastaajista, joiden uskossa ja hengellisyydessä oli tapahtunut muutosta, kertoi uskonsa syventyneen. Poikkeuksellinen aika oli saanut heidät hakeutumaan hengellisten asioiden äärelle aikaisempaa useammin. Jumalan läsnäolo oli tuntunut erityisen läheiseltä ja jumalanpalvelusyhteyden puuttuminen oli saanut ihmiset huomaamaan, kuinka tärkeä asia usko on omassa elämässä. Esimerkiksi L62 kuvasi uskoa tärkeänä jaksamista ja kestävyyttä tukevana asiana: "Se on vahvistanut luottamusta kaikkivaltiaaseen Luojaan ja Lunastajaan. Hänen varassaan on turvallista elää ja kuolla. Kaikki on lopulta Hänen käsissään.”Toisaalta lähes joka viides (17 \%) niistä luterilaisen seurakuntalaiskyselyn vastaajista, jotka kokivat pandemian vaikuttaneen heidän uskoonsa ja hengellisyyteensä, koki uskonsa heikentyneen. Tähän vaikutti ennen kaikkea hengellisen elämän köyhtyminen seurakuntayhteyden puuttumisen takia.

Rukous on yleisin uskonnollinen selviytymiskeino (esim. Hood ym., 2018:489). Se ylläpitää jaksamista ja luo hengellistä kestävyyttä. Puolet (49 \%) luterilaisaineiston vastaajista kertoi, että pandemia vaikutti heidän rukouselämänsä märään ja säännöllisyyteen, kun vastaavasti toinen puolisko (51 \%) vastaajista koki, ettei pandemialla ollut vaikutusta asiaan. Suurin osa niistä vastaajista, joiden rukouselämän määrässä ja säännöllisyydessä oli tapahtunut muutoksia, oli rukoillut aikaisempaa useammin. Rukousaktiivisuuden kasvuun olivat syynä poikkeukselliset tapahtumat, jolloin ihmiset olivat kokeneet tarvetta rukoilla enemmän. Lisäksi osa vastaajista oli kokenut, että heillä oli aikaisempaa enemmän aikaa rukoilla esimerkiksi etätöiden mahdollistaman vapaamman päivärytmin ansiosta. Vähentyneeseen rukousaktiivisuuteen oli puolestaan vaikuttanut seurakuntayhteyden heikentyminen sekä arjessa pandemian takia tapahtuneet muutokset, jolloin rutiini rukoiluun oli särkynyt.

Ortodoksiaineistossa rukouselämän muutosta koskevissa vastauksissa on erotettavissa kolme ryhmää. Suurin ryhmä muodostuu vastaajista (30 \%), jotka kertoivat, ettei koronatilanne ollut vaikuttanut heidän rukouselämänsä säännöllisyyteen. Lähes yhtä suuren (28 \%) määrän muodostivat ne, jotka kertoivat tilanteen vahvistaneen rukouselämää ja -aktiivisuutta varsinkin koronakriisin 
alkuvaiheessa. Rukouselämän vahvistumista olivat tukeneet esimerkiksi hiljaisuuden lisääntyminen, keskittyminen itsetutkisteluun, hengellisen kirjallisuuden ja Raamatun lukeminen sekä toimeliaisuuden vähentyminen. Poikkeusolojen seurauksena "rukoukset on tullut luettua enemmän ajatuksella ja säännöllisemmin" (O5) ja "sydämen rukous" (O133) sekä sanattomat "rukoushuokaukset ovat lisääntyneet" (O47). Yksittäiset ortodoksiaineiston vastaajat kertoivat kokeneensa velvollisuudekseen ottaa poikkeusoloissa enemmän henkilökohtaista vastuuta rukouksesta. Koronatilanteessa rukous keskittyi kotialttarin äärelle, kuten vastaaja O248 kirjoitti:"[Rukouksen] määrä on lisääntynyt merkittävästi. Lampukassa on liekki aina kun olen kotona."

Kolmanteen ryhmään kuului viidennes ortodoksiaineiston vastaajista (20 \%). He kertoivat koronatilanteen heikentäneen rukouselämää. Yleensä vastaajat totesivat rukoukseen käytetyn ajan vähentyneen kuitenkaan muutoksen laajuutta tai siihen vaikuttaneita syitä tarkemmin kuvaamatta. Jos muutoksen taustoja avattiin, seurakunnan jumalanpalvelusyhteyden puuttuminen mainittiin useimmin. Vastauksissa toistui havainto, että henkilökohtainen rukouselämä on "hyvin paljon yhteiseen rukoukseen sidottua" (O14), jolloin ilman jumalanpalveluksien tarjoamaa tukea rukoileminen "on muuttunut vaikeammaksi” (O28). Lisäksi esimerkiksi lapsiperhetilanteessa etätyöskentely, lastenhoito ja kotikoulun organisoiminen eivät jättäneet aikaa ja voimia rukoukselle ja jumalanpalvelusten seuraamiselle. Osassa vastauksia muutosta tarkennettiin toteamalla, että vaikka rukous onkin vähentynyt, on se sitäkin hartaampaa tai "laadukkaampaa" (O90). Toisaalta yksittäiset vastaajat kertoivat rukouselämänsä pysähtyneen kokonaan koronaepidemian vuoksi.

Molemmissa seurakuntalaisaineistoissa usein toistuva syy lisääntyneelle rukouselämälle oli koronatilanteen aiheuttama huoli itsestä, läheisistä ja maailmasta. Globaali kriisi vaikutti myös rukouselämän sisältöihin. Yli puolella (60 \%) luterilaiseen kyselyyn vastanneista rukouselämän painotukset olivat muuttuneet pandemian vaikutuksesta. Vastaajista 40 prosenttia puolestaan kertoi, ettei pandemialla ollut vaikutusta heidän rukouselämänsä sisältöihin ja painotuksiin. Niillä vastaajilla, joiden rukouselämän sisällöissä ja painotuksissa oli tapahtunut muutoksia, rukoukset olivat painottuneet entistä enemmän esirukouksiin toisten ihmisten ja koko maailman puolesta (42 \% niistä vastaajista, joiden rukouselämän sisältöihin ja painotuksiin pandemialla oli ollut vaikutusta). Vastaajat kertoivat rukoilleensa muun muassa oman maan ja sen päättäjien puolesta, sairaiden ja sairautta pelkäävien sekä terveydenhoi- 
don henkilökunnan puolesta, opettajien ja tutkijoiden puolesta sekä lasten, vanhusten ja riskiryhmiin kuuluvien puolesta. Esirukousten lisäksi luterilaisaineiston vastaajat olivat rukoilleet pandemian poistumisen ja oman elämän puolesta. Osalla vastaajista oman henkilökohtaisen uskon merkitys oli korostunut rukouksissa ja muutamilla vastaajilla kiitosrukoukset olivat lisääntyneet.

Myös ortodoksiaineistossa näkyy, että koronatilanteen koko yhteiskuntaan ulottuva vaikutus voimisti toiset huomioivaa esirukousta. Kysyttäessä koronakriisin näkymisestä rukouksen sisällöissä, vastauksissa tuli voimakkaasti esille läheisten terveyden ja koronapandemian loppumisen puolesta rukoileminen sekä koronaan sairastuneiden, riskiryhmiin kuuluvien, koronatoimista vastuussa olevan esivallan ja hoitohenkilökunnan muistaminen. Koronatilanne näyttää siten suoraan ja vahvasti vaikuttaneen esirukousaiheisiin. Esimerkin esirukousteemojen sanoittamisesta tarjoaa O103:n vastaus: "Olen rukoillut tämän epidemian loppumista, varjelusta tältä sairaudelta kaikille läheisilleni, kaikille ihmisille ylipäätään.” Koronatilanne saattoi myös avata uudella tavalla kirkon yhteisiä rukouksia, kuten O173 kuvasi: "Miten todeksi voikaan tulla 'sästä meidät sodan jaloista, kulkutaudeista'. Ei ole pelkkää sanahelinää, vaan tilanne voi muuttua tosi nopeasti."

Ortodoksiselle kristillisyydelle tunnusomaisista piirteistä ortodoksiaineistossa korostui kääntyminen pyhien ihmisten puoleen. Poikkeusoloissa tiettyjen pyhien ihmisten läsnäolo koettiin aiempaa voimakkaammin. Vastauksissa mainittiin nimeltä useita pyhiä, muun muassa Ksenia Pietarilainen ja Efraim Syyrialainen, sekä toistuvasti palkatta parantajat tärkeäksi koettuna pyhien ryhmänä. Eniten vastaajat olivat tukeutuneet Jumalanäitiin eli Neitsyt Mariaan. Ortodoksisessa kristillisyydessä Marialla on keskeinen rooli esirukoilijana, ja hänen perinteestä nousevia nimityksiään ovat muun muassa "kaikkien kristittyjen turva" ja "murheellisten ilo" (Cunningham, 2015). Luterilaisessa aineistossa Jumalan lisäksi vain Jeesus mainittiin eksplisiittisesti turvautumisen kohteena (4\% vastauksista), joka "on tullut tosi rakkaaksi ja lähelle" (L9) ja "johon voin luottaa" (L56). Kirkolliset traditiot näkyvät voimakkaasti siinä, kenen puoleen ihmiset kertovat kääntyneensä hengellistä apua etsiessään.

\section{Johtopäätökset}

Koronapandemia on ollut Suomessa merkittävä yhteiskunnallinen kriisi, johon on reagoitu valtion turvallisuusstrategian kokonaisturvallisuuden mal- 
lin mukaisesti. Kirkkojen tehtävänä on ollut edistää suomalaisten sosiaalisen osallisuuden kokemuksia ja verkostoja osana kansalaisten henkistä kriisinkestävyyttä. Haastavaksi näiden suojaavien tekijöiden edistämisen on tehnyt pandemian luonne kriisinä, joka on pakottanut ihmiset pitämään fyysistä etäisyyttä ja omaksumaan poikkeusolojen erilaiset käytännöt.

Tässä artikkelissa olemme tutkineet, miten Suomen ortodoksisen kirkon ja Suomen evankelis-luterilaisen kirkon striimattuihin jumalanpalveluksiin osallistuneet suomalaiset ovat kokeneet hengellisen yhteyden ja millaisia muutoksia heidän hengellisyydessään on tapahtunut koronakriisin ensimmäisen aallon aikana keväällä ja kesällä 2020.

Tutkimuksemme osoittaa koronakriisin vahvistaneen solidaarisuutta, lähimmäisten hyvinvoinnista huolehtimista ja hengellistä elämää kyselyihin vastanneiden keskuudessa. Tämä näkyy vastauksissa esimerkiksi esirukousaiheiden laajentumisessa ja hengellisenä huolenpitona muun muassa perheenjäsenistä, terveydenhuoltohenkilökunnasta ja koronaan sairastuneista sekä uudenlaisissa hengellisen elämän ja yhteyden muodoissa, esimerkiksi jopa satoja ihmisiä yhdistäneissä rukousverkostoissa. Henkilökohtaisen uskon syventyminen ja yksityisen rukouksen lisääntyminen nousivat niin ikään keskeisiksi teemoiksi molempien kirkkojen toimintaan osallistuneiden kokemuksissa.

Striimatut jumalanpalvelukset toivat molemmissa aineistoissa esille uudenlaisia osallisuuden tapoja. Esimerkiksi sellaiset seurakuntalaiset, jotka kokivat, etteivät saa tai uskalla laulaa kirkkotilassa jumalanpalveluksissa, saattoivat kokea uudenlaista osallisuutta palveluksesta laulaessaan virsiä tai veisuja striimin äärellä. Pandemian maailmanlaajuinen luonne ja mahdollisuus osallistua striimin kautta laajasti kirkollisiin tilaisuuksiin lisäsivät myös osallisuuden kokemusta suhteessa universaaliin kirkkoon. Näin ollen striimatut jumalanpalvelukset mahdollistivat yhteyden ja hengellisen elämän ylläpitämisen (tai synnyttämisen) tilanteessa, jossa hengelliset tarpeet ja huoli omasta ja lähimmäisten hyvinvoinnista voimistuivat. Vaikka striimatut jumalanpalvelukset ja muut hengelliset tilaisuudet olivat yhteyttä ja hengellistä elämää ylläpitävä tekijä, niiden toisaalta todettiin korvaavan fyysistä yhteen kokoontumista varsin vaillinaisesti. Poikkeavalla tavalla toteutettu yhteisöllinen uskonnonharjoitus myös hämmensi osaa striimattuihin palveluksiin osallistuneista. Samalla kun kirkkojen sulkeutuminen ja toiminnan siirtyminen verkkoon osoitti yhteisen jumalanpalveluksen merkityksen, muutos vaikutti polarisoivasti kirkkojen toimintaan osallistuvien hengellisen yhteyden kokemukseen. 
Huomionarvoista onkin, että sekä luterilaisen että ortodoksisen kirkon piirissä kyselyihin vastanneista lähes yhtä suuret osuudet vastaajista kuvasivat hengellisen elämänsä joko vahvistuneen tai heikentyneen. Hieman alle puolet luterilaisvastaajista ja noin kaksi kolmannesta ortodoksivastaajista toi esiin merkkejä hengellisestä hyvinvoinnistaan, joka on aiemmassa tutkimuksessa katsottu merkitykselliseksi kriisitilanteista ja -ajoista selviytymiseen. Monelle vastaajalle pandemian ensimmäisen aallon aika oli sen sijaan yhteyden kokemusta ja hengellistä hyvinvointia heikentävä. Ortodoksisen kirkon toimintaan osallistuneista noin kolmannes koki seurakuntayhteyden heikentyneen. Ortodoksiaineiston vastauksissa tuli myös voimakkaasti ilmi henkilökohtaisen ja seurakunnan yhteisen rukouksen välinen yhteys: fyysisen rukousyhteyden puuttuminen toisiin koettiin myös henkilökohtaisen rukouselämän kuihtumisena. Myös luterilaisaineistossa korostui fyysisen yhteyden katkeamisen vaikutus hengelliseen elämään: hieman yli puolet luterilaisvastaajista koki yhteyden omaan seurakuntaan heikentyneen poikkeusolojen aikana. Yksittäiset vastaajat kokivat sen jopa kadonneen.

Lukuisat vastaajat kertoivat koronatilanteen lisänneen ahdistuneisuutta sekä heikentäneen elämänhallintaa. Kokemukset näyttävät olevan suorassa yhteydessä yksinäisyyden ja erillisyyden lisääntymiseen, jota vähentynyt tai kokonaan katkennut seurakuntayhteys vahvisti. Muutokset osoittavat, että kirkollisen toiminnan alueelle sijoittuvat sosiaaliset ja hengelliset verkostot ovat merkityksellisiä mutta eristäytymistä vaativina aikoina jopa hauraita.

Kehollisuuden ja aistikokemusten olennaisuus osana yhteyden kokemista näkyivät aineistoissamme. Vastaajat ilmaisivat kaipausta fyysiseen läsnäoloon muun seurakunnan kanssa. Yhteinen osattomuus perinteisestä jumalanpalveluksesta teki monelle näkyväksi samassa tilassa tapahtuvan jumalanpalveluksen kokonaisvaltaisuuden: äänimaailman, tuoksut, katseet, kosketukset ja vuorovaikutuksen. Toisaalta striimatut jumalanpalvelukset toivat niihin osallistuneille jumalanpalveluksen seurakuntalaisten kotiin ja siten myös yksityisen elämän piiriin. Kotona vietetty jumalanpalvelus oli useimmille vastaajista muodoltaan vapaampi, ja sen äärellä saattoi istumisen tai seisomisen sijaan makoilla tai tehdä kotitöitä. Osalle vastaajista tämä arkipäiväisti kokemusta jumalanpalveluksesta ja usein heikensi yhteyden kokemusta, mutta toisille se näyttää tuoneen kokemuksen kotielämän pyhittymisestä ja hengellisen elämän voimakkaammasta nivoutumisesta siihen. 
Ortodoksikyselyyn vastanneet olivat keskimäärin osallistuneet striimattuihin jumalanpalveluksiin useammin kuin luterilaiskyselyyn vastanneet, vaikka ortodoksikysely toteutettiin aiemmin poikkeusolojen alettua. Havainto voi osaltaan viestiä kyselyyn vastanneiden ortodoksien tiiviimmästä seurakuntayhteydestä, mutta sitä ei voida laajentaa koskemaan ortodoksisen kirkon jäseniä yleensä. Selittävä tekijä voi olla myös ortodoksien harvempi pyhäkköjen verkosto: striimatut palvelukset ovat voineet tavoittaa syrjäseuduilla ja pienillä paikkakunnilla asuvia ortodokseja, joilla ei ole mahdollisuutta osallistua fyysisesti toimitettuun jumalanpalvelukseen. Luterilaiskyselyn vastaajien keski-ikä oli huomattavasti matalampi kuin ortodoksikyselyn vastaajien (ks. taulukko sivulla 6). Näin ollen mahdollinen oletus siitä, että striimatut palvelukset tavoittaisivat ensisijaisesti nuoria seurakuntalaisia, ei kokonaisaineistomme valossa ole selitysvoimainen. Näyttäisi siten siltä, että kyselyjen levittämiskanavilla (kirkon vs. yliopiston internetsivusto) on suurehko merkitys vastaajien valikoitumiseen, mikä näkyy erityisesti vastauksissa kysymyksiin jumalanpalveluselämään osallistumisesta.

Vaikka koronakriisi on aiheuttanut suomalaisissa samalla etenkin terveydellisiä ja taloudellisia huolia (Salomäki, 2020c), esimerkiksi vastaajien henkilökohtaiset taloudelliset huolet eivät nouse aineistoissamme esille. Kenties omaan talouteen liittyvät huolet koettiin globaalin kriisin alkuvaiheessa vielä niin merkityksettömiksi, ettei niitä haluttu tuoda esille. Mahdollisesti ne saatettiin myös kokea liian maallisiksi asioiksi kirkollista elämää koskevassa kyselyssä. Joka tapauksessa tutkimuksemme tukee aiempia havaintoja uskon vahvistavasta ja merkityksiä antavasta luonteesta kriisitilanteissa. Lisäksi tuloksemme vahvistavat käsitystä hengellisen maailmankatsomuksen ja hengellisen hyvinvoinnin merkityksestä osana ihmisen kokonaisvaltaista hyvinvointia ja kriisinkestävyyttä.

Aineistomme mukaan koronapandemia ja siitä seuranneet poikkeusolot ovat heijastuneet paitsi hyvinvointierojen voimistumiseen myös polarisaatioon yhteyden ja osallisuuden kokemuksissa. Nähdäksemme yhä edelleen tarvitaan lisätutkimusta siitä, mitkä henkilökohtaiset tai yhteisölliset tekijät johtavat kokemukseen yhteyden rakentumisesta, hengellisestä osallisuudesta tai osattomuudesta ja sitä kautta inhimillisestä hyvinvoinnista ja jaksamisesta, sillä ne vaikuttavat paitsi yksilö- ja paikallisyhteisöjen tasolla, myös koko yhteiskunnan kriisinkestävyyteen. 


\section{Lähteet ja kirjallisuus}

Seurakuntalaisaineistot $(\mathrm{N}=555)$ kirjoittajien hallussa.

Amjad, F. \& Bokharey, Z. (2014). The Impact of Spiritual Wellbeing and Coping Strategies on Patients with Generalized Anxiety Disorder. Journal of Muslim Mental Health, 8(1), 21-38. https://doi.org/10.3998/ jmmh.10381607.0008.102

Arkkipiispan ohjeet. (2020). Arkkipiispan asettaman työryhmän ohjeet. Ort. fi 17.3.2020. https://ort.fi/uutishuone/2020-03-17/arkkipiispan-asettamantyoryhman-ohjeet - Viitattu 12.1.20201.

Baumeister, R. \& Leary, M. (1995). The Need to Belong: Desire for Interpersonal Attachments as a Fundamental Human Motivation. Psychological Bulletin, 117(3), 497-529. https://doi.org/10.1037/00332909.117.3.497

Chirico, F. (2016). Spiritual well-being in the 21st century: it's time to review the current WHO's health definition. Journal of Health and Social Sciences, 1(1), 11-16.

Cunningham, M. (2015). Gateway of life: Orthodox thinking on the Mother of God. New York: St. Vladimir's Seminary Press.

Eskola, J. \& Suoranta, J. (2001). Johdatus laadulliseen tutkimukseen. Tampere: Vastapaino.

Federico, A. (2015). Engagements with Close Reading. London: Routledge. https://doi. org/10.4324/9781315757759

Fehring, R., Miller, J. \& Shaw, C. (1997). Spiritual well-being, religiosity, hope, depression, and other mood states in elderly people coping with cancer. Oncology Nursing Forum, 24(4), 663-671.

Fisher, J. (2011). The Four Domains Model: Connecting Spirituality, Health and Well-Being. Religions, 2, 17-28. https:// doi.org/10.3390/rel2010017

Gonzalez, P. et al. (2014). Spiritual well-being and depressive symptoms among cancer survivors. Support Care Cancer 22, 23932400. https://doi.org/10.1007/s00520014-2207-2
Hanhirova, M. \& Aalto, K. (2009). Ihmisen hengelliset tarpeet. - K. Aalto \& R. Gothóni (toim.), Ihmisen lähellä. Hengellisyys hoitotyössä. Helsinki: Kirjapaja, 9-23.

Hattunen, Maria (2021). Suomen ortodoksisen kirkon vastaava tiedottaja Pekka Metsolle. Sähköposti 24.2.2021.

Heintzman, P. \& Mannell, R. (2003). Spiritual Functions of Leisure and Spiritual Well-Being: Coping with Time Pressure. Leisure Sciences, 25(2-3), 207-223. https:// doi.org/10.1080/01490400306563

Hood, R. W. Jr., Hill, P. \& Spilka, B. (2018). The psychology of religion: an empirical approach. Fifth edition. New York, London: The Guilford Press.

Jumalanpalvelukset siirtyvät nettiin. (2020) Jumalanpalvelukset siirtyvät nettiin, mutta ehtoolliselle pääsy halutaan turvata. Hos. fi 18.3.2020. https://www.hos.fi/jumalanpalvelukset-siirtyvat-nettiin-mutta-ehtoolliselle-paasy-halutaan-turvata/ - Viitattu 12.1.2021.

Kallatsa, L. \& Mikkola, S. (2020). "Olimme kaikki osallisia kaipuun sakramentista". Ehtoollinen ja kirkkoherrojen kokemukset Suomen evankelis-luterilaisessa kirkossa koronakeväänä 2020. Uskonnontutkija, 9(2), 27 s. https://doi.org/10.24291/ uskonnontutkija.v9i2.100611

Kallinen, T. \& Kinnunen, T. (s.a.). Etnografia. - J. Vuori (toim.), Laadullisen tutkimuksen verkkokäsikirja. Tampere: Yhteiskuntatieteellinen tietoarkisto. https://www.fsd. tuni.fi/palvelut/menetelmaopetus/ - Viitattu 13.6.2021.

Karppanen, E. (2007). Kirkon rooli kollektiivissa kriiseissä. Kirkon tutkimuskeskuksen www-julkaisuja 13. https://evl.fi/documents/1327140/45386794/Www-julkaisu+13_Karppanen+\%28Kirkon+rooli+kollektiivisissa+kriiseiss\%C3\%A4\%29. pdf/1bf2fc83-8fa9-8a63-6d25-cdcfd0662cb2 - Viitattu 13.1.2021.

Karvinen, I. (2012). Henkisyys ja hengellisyys keskeisissä suomalaisissa hoitotyön julkaisuissa. Diakonian tutkimus 2, 196-210. 
Keskustelutoiminto kirkon etusivulle. (2020). Ort.fi 17.3.2020. https://ort.fi/uutishuone/2020-03-17/keskustelutoiminto-kirkon-etusivulle - Viitattu 13.1.2021.

Kirkon tutkimuskeskus. (2021). Koronavirus näkyy kirkon toiminnassa. Kirkon tutkimuskeskuksen koronaseuranta. https://public.tableau.com/profile/kirkon.tutkimuskeskus\#!/ vizhome/Koronakriisi_seuranta/Koronakriisinvaikutukset - Viitattu 11.1.2021.

Louheranta, O., Lähteenvuo, M. \& Kangasniemi, M. (2016). Henkinen ja hengellinen tuki terveydenhuollossa - kenen vastuulla? Sosiaalilääketieteellinen aikakauslehti, 53, 234-241.

Ortodoksisen kirkon palveleva puhelin. (2020). Suomen ortodoksisen kirkon palveleva puhelin aloittaa. Ort.fi 18.3.2020. https://ort.fi/uutishuone/2020-03-18/ suomen-ortodoksisen-kirkon-palveleva-puhelin-aloittaa - Viitattu 13.1.2021.

Saarelainen, S-M. (2020). Ibmisten henkinen byvinvointi ja koronakriisi. Paneelikeskustelu: Kirkot, uskonto ja hyvä elämä koronakriisin keskellä. Teologian ja uskonnontutkimuksen päivät, Helsinki 10.9.2020.

Salomäki, H. (2020a). Suomalaisten jaksaminen koronakriisissä. Seurantakyselyn raportti. Tampere: Kirkon tutkimuskeskus. https://evl.fi/ documents/1327140/50112189/Suomalaisten+jaksaminen+koronakriisiss\%C3 \%A4_koronan+uusintakysely_saavutettava.pdf/3ca90cc9-6fc7-5ca8-2dca-e72aa2f5adf1?t=1596613471083 - Viitattu 11.1.2021.

Salomäki, H. (2020b). Seurakunnat ja koronakriisi. Raportti kirkon työntekijoille ja luottamushenkilöille tehdystä kyselystä. Tampere: Kirkon tutkimuskeskus. https://evl. fi/documents/1327140/50112189/Seurakunnat+ja+koronakriisi+2020.pdf/ 69a939cd-e0c2-4803-9422-af53ca80c$4 d b ? t=1590475691191$ - Viitattu 11.1.2021.

Salomäki, H. (2020c). Suomalaisten henkinen kriisinkestävyys. Huolenaiheetja turvallisuutta tuovat tekijät koronakriisissä. Tampere: Kirkon tutkimuskeskus. https://evl.fi/documents/1327140/50112189/Suomalais-
ten+jaksaminen+koronakriisiss\%C3\%A4 koronan+uusintakysely_saavutettava. pdf/3ca90cc9-6fc7-5ca8-2dca-e72aa2f5adf1?t=1596613471083 - Viitattu 11.1.2021.

Silverman, D. (2006). Interpreting Qualitative Data. Methods for Analyzing Talk, Text and Interaction. Los Angeles: Sage Publications.

Toivanen, M. (2020). Ministeri Annika Saarikko kirkolliskokoukselle: Kirkon toiminta on tärkeä osa henkistä kriisinkestävyyttä. Kotimaa 12.8.2020. https://www. kotimaa.fi/artikkeli/ministeri-annika-saarikko-kirkolliskokoukselle-kirkon-toiminta-on-tarkea-osa-henkista-kriisinkestavyytta/ - Viitattu 16.2.2021.

Valtioneuvosto. (2017). Yhteiskunnan turvallisuusstrategia. Valtioneuvoston periaatepäätös. Helsinki: Turvallisuuskomitea. https:// turvallisuuskomitea.fi/wp-content/uploads/2018/02/YTS_2017_suomi.pdf Viitattu 12.1.2021.

Unterrainer, H.-F. et al. (2010). Dimensions of Religious/Spiritual Well-Being and their relation to Personality and Psychological Well-Being. Personality and Individual Differences, 49(3), 192-197. https:// doi.org/10.1016/j.paid.2010.03.032

Unterrainer, H.-F., Lewis, A., Collicutt, J. \& Fink, A. (2013). Religious/Spiritual Well-Being, Coping Styles, and Personality Dimensions in People with Substance Use Disorders. The International Journal for the Psychology of Religion, 23(3), 204213. https://doi.org/10.1080/10508619.2 012.714999

Valtioneuvosto. (2020). Koronakriisin vaikutukset ja suunnitelma epidemian hallinnan bybridistrategiaksi. Exit- ja jälleenrakennustyöryhmän 1. vaiheen raportti. Helsinki: Valtioneuvosto. https://julkaisut.valtioneuvosto.fi/bitstream/handle/10024/162214/ VN_2020_12.pdf?sequence=1\&isAllowed =y - Viitattu 12.1.2021.

Voicu, B. et al. (2020). COVID-19 and orientations towards solidarity: the cases of Spain, Hungary, and Romania. European Societies, S887-S904. https://doi.org/10.1 080/14616696.2020.1852439 